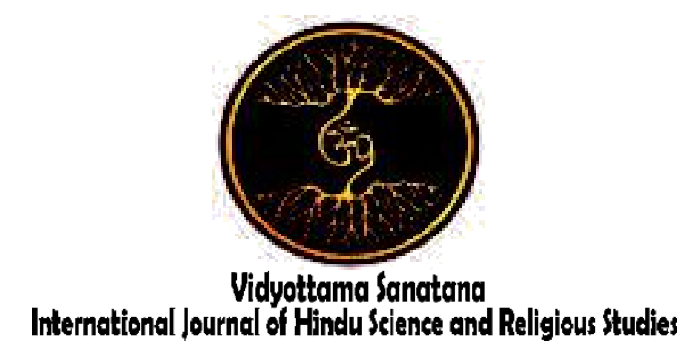

Vol. 4 No. 1 May 2020

\title{
NEKARA PEJENG AS A LEARNING RESOURCES OF EDUCATION HINDU RELIGION
}

\author{
By: \\ I Nyoman Subagia \\ Universitas Hindu Negeri I Gusti Bagus Sugriwa Denpasar \\ E-mail : nyomansubagia1182@gmail.com
}

Received: April 30, 2020

Accepted: May 12, 2020

Published: May 30, 2020

\begin{abstract}
Nekara Bronze in Pejeng, has a uniqueness that is still trusted by the surrounding community until now, where the Nekara Bronze is believed to be a drum to call rain. However, not all are aware of, understand the message or meaning of the Nekara Pejeng. The main problem of this research is to review Nekara Pejeng as a source of learning for Hindu religious education. The purpose of writing covers the history of Nekara Pejeng, and Nekara Pejeng as a source of learning for Hindu religious education. Data collection methods used were active participation observation techniques, in-depth interviews and document studies. The data collected is processed with qualitative descriptive techniques to see certain dimensions of the aspects being measured. The results of the analysis show that, students can observe diverse facts up close about the existence of Nekara Pejeng, students can experience new experiences by participating in an activity, students can answer problems or questions by seeing, listening, try, and prove firsthand. In conclusion, Nekara Pejeng as a source of learning has many advantages; learning becomes more meaningful and real. This means that students are required to be able to capture the relationship between learning experiences on campus with real life.
\end{abstract}

Keywords: nekara pejeng, learning resources, Hindu religious education

\section{INTRODUCTION}

The biggest bronze Nekara located in Penataran Sasih Temple is $186.5 \mathrm{~cm}$ in size and with a diameter of $160 \mathrm{~cm}$. Nekara is considered to be very holy and rescued by the people in the village. Pejeng. Nekara is placed in a pelinggih called Ratu Sasih. Pejeng villagers believe that Nekara is a part of the moon that falls from the sky. So that the Penataran Sasih Temple comes from the name of the month (Sasih, Bulan), Wahyuni, 2014: 4). 
In utilizing cultural objects as a source of learning, it is necessary to explore and utilize the surrounding environment as a source of learning in the form of Nekara Pejeng cultural objects stored in Penataran Sasih Temple. Of the temples in Tampaksiring District, one of them is interesting to study, namely the Bronze Nekara in Penataran Sasih Temple. This temple is believed to have existed since the days of Ancient Bali and remains sacred until now. In the opinion of the Archaeologists, historical relics that were preserved in the Penataran Sasih Temple in the form of Bronze Nekara which is a legacy of the cultural traditions of the Dong Son community in the North Vietnam region which also developed in Indonesia, including some that spread into the interior of Kalimantan, Sumatra and in Bali. Nekara Pejeng is the largest Nekara in Asia found to date (Swastika 1998, 11).

Nekara "Pejeng Month" is the work of bronze age culture or also called the age of 142 , perundagian. It is called the bondage period because at that time the undagi or those who had special skills as undagi had made various bronze objects, especially nekara. As one of the leading cultural products that are made excellent as a tourist attraction, it has uniqueness, which has a large size, including one of the largest nekara in Southeast Asia including the local type (Pejeng type), the type that is not possessed by other nekara (Butzer 1971, 34).

Nekara Pejeng is $1.98 \mathrm{~m}$ tall, longer than its width. The 1.60-in. Diameter area pushes $25 \mathrm{~cm}$ outward from the shoulders straight down and curves inward at the cylindrical waistline. Clap-shaped legs that widen at the bottom. Nekara Pejeng also holds various myths about "Pejeng Month", the Bronze Nekara stored in Penataran Sasih Temple is often called "Pejeng Month", with a size of $186.5 \mathrm{~cm}$, Nekara Pejeng was rescued by the Pejeng Village community (Iskandar 2009, 45). While Sutaba (1980, 24), said the existence of the Bronze Nengara Pejeng is associated with the myth of the existence of "Pejeng Moon" with the story of Pissing Meguna. In addition to the uniqueness found in the reliefs of Nekara Bronze in Pejeng, there is also a uniqueness that is still trusted by the surrounding community until now, where Nekara Bronze is believed to be a drum to call down the rain. However, not all are aware of, understand the message or meaning of the Nekara Pejeng, therefore research on Nekara Pejeng as a learning resource for Hindu religious education is held.

In connection with the description, the problem that is the basis of the review is how Nekara Pejeng as a source of learning Hindu education. The purpose of writing covers the history of Nekara Pejeng, and Nekara Pejeng as a source of learning for Hindu religious education. The scope of the discussion is limited to the data of Nekara Pejeng located in Penataran Sasih Pejeng Temple, Tampaksiring District, Gianyar Regency.

\section{METHOD}

This research uses the type of field research (field research), because this research takes place in the field both in real and fact field by collecting data and information from related real life. The form of approach that the author uses in this study is a qualitative approach, which is a research procedure that produces descriptive data in the form of written or spoken words of people needed that can be observed which are carried out in real and actual life (Meleong 2014, 70). In this study, data collection instruments were used. Data analysis of the results of preliminary research was carried out using a descriptive approach accompanied by a narrative that was in accordance with the research interests.

\section{RESULTS AND DISCUSSION \\ 3.1 History of Nekara Pejeng}

The biggest bronze Nekara, located in Penataran Sasih Temple, is thought to have been used before in the rain rain ceremony. Many legends about this nekara, one of which is that this nekara was a wheel of the sky train that spreads bright light, so that at night it was always bright. Another legend says that this nekara is ear jewelry from Dewi Ratih (Dewi Bulan in Balinese mythology). It is said that 
long ago there were 13 months on earth. One day one of these months fell to the earth and stuck in a tree branch. The light emitted this month is so bright that no thief dares to steal it at night. But once the thieves conferred and they agreed to extinguish the moon, one of them climbed the tree and with his little water he tried to extinguish the moon which was covered with flames. Instantly the moon exploded and one of the fragments of the moon became the captivity of the Pejeng moon. The damage that was behind the nekara was said to have originated from the explosion (Soekmono, 1988: 38).

Swastika $(1998,11)$ states that nekara is the product of the Dongson Culture of North Vietnam, because the Dongson culture had developed in 300 BC. Meanwhile, the influence of Hinduism in Bali is estimated to be only around the 8th century. Nekara in the Penataran Sasih Temple as a ceremonial drum that was struck with religious rules as a means of worship. This is based on Nekara's animalshaped and sun-shaped decoration with eight rays, besides the decoration there is also a central circle strip motif, and on Nekara's body there are eight people's heads facing eight directions.

Nekara is made of bronze with a waist in the middle and the top side closed. This form of nekara can be likened to a caged cup. Nekara as a result of the dating period, has a unique form with complex decorative patterns. The form of nekara is generally arranged in three parts. The upper part consists of a flat o'clock area and the shoulder part with a handle. The middle part is cylindrical and the bottom is wide. Decorative patterns found in Nekara are generally in the form of geometric decorative patterns with several variations. For example, decorative patterns are arranged, decorative patterns, and decorative patterns mask. Nekara is also considered a sacred object used during ceremonies.

Nekara bronze is found in many parts of the archipelago. On the island of Sumbawa, bronze nekara-nekara wear decoration patterns in the form of people who are dancing with bird feathers and there are boat decorations. The boat decoration is thought to be a hearse that carried the spirits of people who had died. On Alor Island many nekara are smaller and slimmer than those found in other places. Nekara found in Alor was named Moko. In the area of Manggarai (Flores) people named Moko as "drum drum" or "drums". Moko is usually an heirloom owned by a tribal chief who was then handed down to one of his sons.

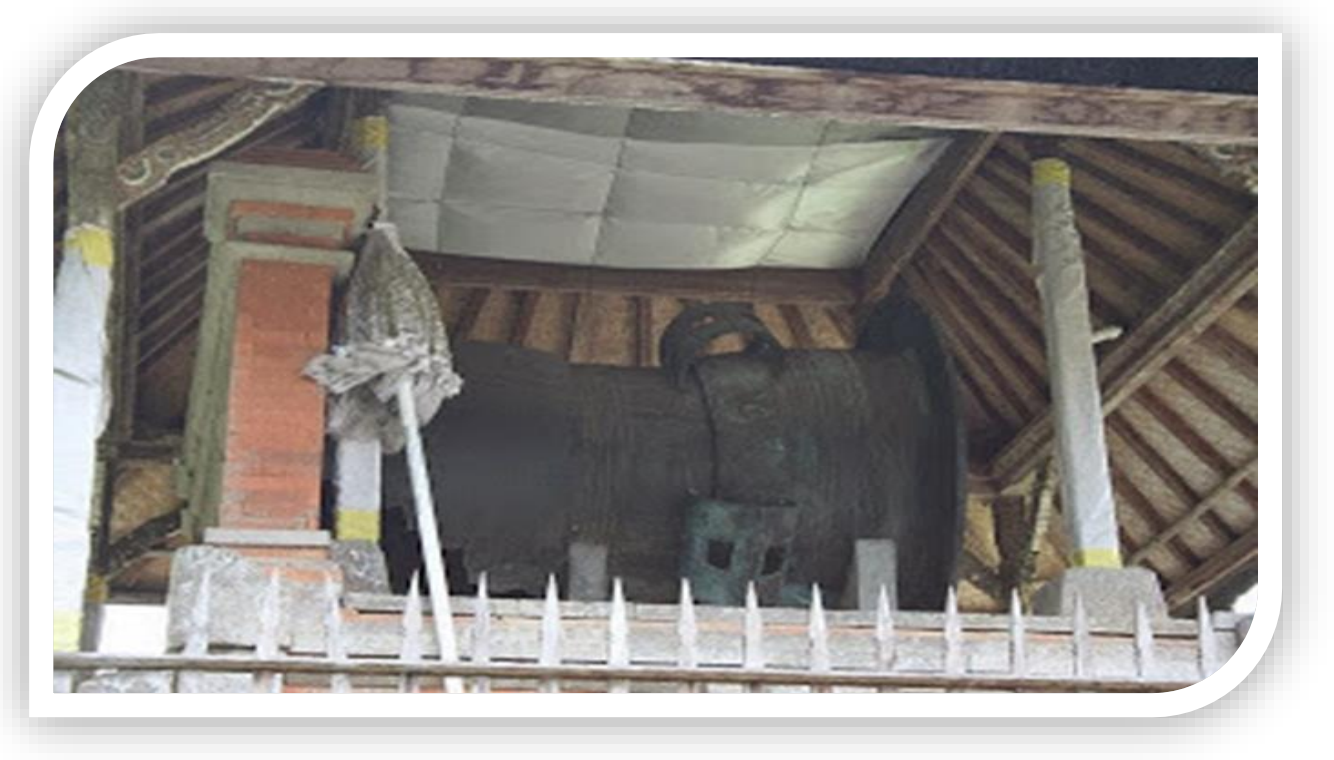

Figure 1. Nekara Pejeng (Source: Personal documents) 


\subsection{Nekara Pejeng as a Learning Resource for Hindu Religious Education}

Learning resources (learning resources) are all sources in the form of data, people and certain forms that can be used by students in learning, both separately and in combination so as to facilitate students in achieving learning goals or achieving certain competencies (Sanjaya 2011, 34) . In order to achieve learning goals, especially religious learning. Religious learning is a complex problem because each student has unique characteristics in learning. This is mainly due to the efficiency of the recipient and the ability of the response. A normal student will be able to get an understanding by processing stimuli from outside which are responded to by his senses, both the senses of sight, hearing, smell, taste and touch.

The process of religious learning that uses the media, it is expected that students who learn not just imitate, imitate or do what is given to him, but how students actively have an effort to do. In the beginning, learning media only functioned as visual aids in learning activities, namely as a means to encourage student learning motivation, clarify and facilitate abstract concepts and enhance their absorption. Then with the influence of technology, various audio visual aids are born which emphasize the use of concrete experiences to avoid verbalism based on their beliefs.

Teaching aids in the form of learning media are also called learning resources, whether in the form of print, non-print or electronic must be well organized by the school, in order to facilitate the process of use by students (students), this process is then centered in a place called the center Learning Resources. The learning development process will take place effectively and efficiently if supported by learning resources that are well managed through the learning resource center. Utilization of learning resource centers is expected to be able to serve all the desires and expectations of students in the learning process. This includes the process of learning Hinduism.
One of the learning resources referred to is Nekara Pejeng as a source of learning Hinduism, learning outside the classroom or commonly known as outdoor learning is a learning activity outside the classroom which is oriented to the natural surroundings which has a pleasant nature and can realize the spiritual value of students regarding the beauty of creation God Almighty by observing, investigating, discovering everything that is created by God Almighty. This learning process can develop and build a fun and challenging and motivating learning environment where students not only interact with one learning source, but can learn from their experience and interactions with the environment to the places visited. Conducting comparative study activities to visit other objects outside the campus is a very appropriate thing to realize it so that the hope to produce quality graduates will be achieved to the maximum.

The strategy and method used is to use the Field Trip Model by utilizing the Nekara Pejeng Site as a source of learning for Hinduism. This is supported by the teaching lecturer in the learning process using the model of learning tour work, because the teaching and learning process in the classroom is not forever effective without the teaching aids as a substitute experience that can strengthen students' understanding of the subject matter provided, but the lack of available teaching aids causes the teaching staff to embed material, while the surrounding environment has the potential to be used as a learning resource as a direct experience that cannot be forgotten students, because the environment is easy for every student to know (Semiawan et al 1989, 96).

So thus, that the use of the environment is very good for planting lecture material, only it needs to be stressed here that the specific learning resources provided are related to the physical environment. Furthermore, in the teaching and learning process in relation to learning resources outside campus, Suleiman (1981, 13-14) argues as real experience not experience with words or substitute experiences, meaning that 
unlike experiences with words, real experience is very effective for get an understanding, because real experience involves all the senses and reason. Real experience is a reasonable and satisfying way of learning. If all people can get real experience and have intelligence that can absorb a comprehensive understanding of all aspects of all those experiences, it will be able to develop the best possible understanding of all that they experience.

Direct experience is very useful for teaching that requires proof in the field. Bringing students off campus can be considered a method of field trip, as suggested by Witerington et al $(1982,62)$, life between the four classroom walls is very limited. Outside the classroom they are faced with a life that is rich in things they can learn. Excursion is not a picnic but it moves the class temporarily out, the duration may be a few minutes or an hour, maybe also a few days or months. With field trips, using resources from the environment and strengthening relationships between the campus and the community, from a didactic angle, many trips have good benefits, such as arousing interest, activities, and so on.

Field trips or excursions are indeed not to linger outside the campus/class, but with limited time can be done, especially activities that are around campus. Field trips as outdoor studies certainly have many advantages, such as; 1) students can observe diverse facts up close about the existence of Nekara Pejeng, 2) students can experience new experiences by participating in an activity, 3) students can answer problems or questions by seeing, listening , try, and prove directly, 4) students can get information by holding interviews or listening to lectures given on the spot, and 5) students can learn something integrally and comprehensively about Nekara Pejeng.

Thus, teaching outside of campus / class has many advantages, compared to teaching only on campus / class, because the existing environment can be used as a useful learning resource. Moreover, to conduct lectures or teaching outside the campus / class without or little cost required, so it does not burden students to do it. In the process of teaching and learning needed a learning model, the learning model is defined as a systematic procedure in organizing learning experiences to achieve learning goals. Can also be interpreted an approach used in learning activities (Suprijono 2009, 34). So, actually the learning model has the same meaning as the approach, strategy or learning method. At present there have been developed various kinds of learning models, from simple to rather complex and complicated models because they require a lot of tools in their application.

So in this research, the learning process outside the classroom by utilizing the Nekara Pejeng site as a learning resource for Hindu religious education is to use CTL. Contextual learning or contextual teaching and learning (CTL) is a learning concept that helps teachers link learning material with realworld situations of students and encourages students to make connections between the knowledge they have and their application in daily life. CTL is a learning system that is suitable for learning Hindu religious education that can be used outside the campus. Students can explore learning resources outside the classroom, lecturers only provide direction, this is important to apply so that the information received is valid, because contextual learning or contextual teaching and learning (CTL) is indeed suitable for use in learning because it emphasizes that learning is not merely memorizing, but reconstructing or building new knowledge and skills through facts or propositions experienced in his life. A competency will be built steadily and maximally if learning is done steadily and maximally if learning is done contextually that is learning that is supported by situations in real life.

\section{CONCLUSION}

Nekara Pejeng as a source of learning has many advantages; learning becomes more meaningful and real. This means that students are required to be able to capture the relationship between learning experiences on campus with real life. This is very important, 
because by being able to correlate material found with real life, not only for students the material will function functionally, but the material learned will be firmly embedded in the memory of students, so it will not be easily forgotten; learning is more productive and able to foster reinforcement of concepts to students, where students are guided to find their own knowledge.

\section{REFERENCES}

Arikunto, S. (1992). Prosedur Penelitian Suatu Pendekatan Praktek. Jakarta: Rhineka Cipta

Bintarti, D. D. (2000). Nekara Tipe Pejeng. Disertasi Universitas Gadjah Mada, Yogyakarta

Budisantoso, T. M. (1996). "Situs-Situs Arkeologi di Kabupaten Ogan Komeering Ulu, Propinsi Sumatera Selatan”. Laporan Penelitian Palembang: Balai Arkeologi Palembang.

Butzer, K. W. (1971). Environment and Archeology: An Intoduction to Pleistocence Georgrapy. Chicago: Aldine Publishing Company.

Kompyang, I D. G. (1995). "Fungsi Moko dalam Kehidupan Masyarakat Alor", Forum Arkeologi Edisi Khusus, no.2, Balai Arkeologi Denpasar.

Kompyang, I D. G. (1997). "Nekara sebagai Wadah Kubur Situs Manikliyu, Kintamani, Forum Arkeologi Edisi Khusus No. II, Balai arkeologi Denpasar.

Hasan Muarif, A. (1997). Dinamika Masyarakat Desa Manikliyu-Bali Menjelang Datangnya Pengaruh Hindu-Budha. Denpasar: Balai Arkeologi Denpasar.

Hoop, V. D. (1932). Megalitic Remains in South Sumatra. Netherlands: W.J. Thieme \& Cie Zutphen: 1-30.

Iskandar, M. D. H. \& Setiawan A. (2009). Sejarah Kebudayaan Indonesia : Sistem Pengetahuan. (Muklis PaEni, Ed). Jakarta: PT Rajagrafindo Persada.

Moleong, L. (2014). Metodologi Penelitian Kualitatif. Bandung: PT Remaja Rosadakarya
Sanjaya, W. (2011). Strategi Pembelajaran Berbasis Kompetensi. Ciputat: Gaung Persada Press.

Semiawan, C. S. (1989). Pendekatan Ketrampilan Proses: Bagaimana Mengaktifkan Siswa dalam Belajar. Jakarta: PT. Gramedia

Soekmono, R. (1988). Pengantar Sejarah Kebudayaan Indonesia. Yogyakarta: Kanisius

Sugiyono. (2005). Metode Penelitian Pendidikan Pendekatan Kualitatif, Kuantitatif, dan RD. Bandung: AlfaBeta

Suleiman, A. H. (1981). Media Audio Visual: Untuk Pengajaran Penerangan dan Penyuluhan. Jakarta: PT. Gramedia

Sutaba, I M. (1980). Prasejarah Bali. B.U. Yayasan Purbakala Bali

Suprijono, A. (2009). Cooperative Learning. Yogyakarta: Pustaka Pelajar Celeban Timur

Swastika, I G. N. (1998). Suaka Peninggalan Sejarah dan Purbakala. Denpasar

Tabrani A. R. (1989). Pendekatan dalam Proses Belajar Mengajar. Bandung: Remadja Rosdakarya.

Titib, I M. (2009). Teologi dan Simbol-Simbol dalam Agama Hindu. Surabaya: Paramita.

Pardi, I W. (2013). Eksistensi Puden Berundak di Pura Candi Desa Pakraman Selulung, Kintamani, Bangli (Kajian Tentang Sejarah dan Potensinya Sebagai Sumber Belajar Sejarah) Skripsi (tidak diterbitkan). Singaraja Jurusan Pendidikan Sejarah Fakultas Ilmu Sosial.

Wahyuni, N. M. A. (2014). "Persepsi Siswa Terhadap Situs Nekara Pejeng Sebagai Sumber Belajar IPS (Studi Kasus Di SMP Negeri 3 Tampaksiring Di Kelas VII A Semester Ganjil Tahun Ajaran 2013/2014, Gianyar Bali)". Widya Winayata: Jurnal Pendidikan Sejarah Vol 2, No 1.

Witherington, HC. (1982). Teknik-Teknik Belajar dan Mengajar. Bandung: Jemmars. 